\title{
Caminhos e Momentos da Criação da Câmara de Política de Humanização da Assistência Hospitalar: a Humanização e a Humanidade nas Práticas, Rotinas e Ações Desenvolvidas em um Hospital Público
}

\author{
Gonçalves, Edson Luis; Castro, Maria Eduarda Oliveira \\ Universidade Federal de Uberlandia - edsonluispedagogo@gmail.com
}

A sociedade passa por mudanças, culturais, políticas, econômicas e sociais. em 2000, nova equipe tem o desafio de administrar a Universidade, a grande expectativa assumida em carta programa: "promover o atendimento humanizado e universal aos que buscam atendimento hospitalar". em janeiro de 2001, assumiu a administração hospitalar, um grupo que, compartilha do mesmo projeto, reafirmou a necessidade de ações de humanização na assistência prestada. Debates definiram os caminhos. Ações em curso, mudanças administrativas e de enfoque, a principal; a Criação da Câmara de Política de Humanização da Assistência Hospitalar, aplicando a Política Nacional de Humanização (PNH), do Ministério da Saúde, objetivando um SUS humanizado. As ações de humanização da assistência hospitalar têm gerado iniciativas de várias equipes no complexo hospitalar. Sem diretrizes da $\mathrm{PNH}$, muitas frentes de trabalho foram apoiadas, exclusivamente, pelas próprias equipes. Desde então, iniciou-se o debate da institucionalização do projeto de humanização. Ação concreta foi a criação do Setor de Humanização, junto à Divisão de Apoio ao Usuário de Saúde do SUS. em outubro de 2001, tem inicio as atividades. Realizou-se uma reunião histórica amplamente divulgada no hospital, para apresentarem as sugestões. Cento e cinquenta pessoas debateram questões de humanização abordando atividades já desenvolvidas pelas equipes de trabalho ou entidades de voluntários vinculadas à área da saúde. das sugestões apresentadas, elegeram 13 prioridades: "Comemoração de datas de nossa cultura; Atenção aos pacientes fora de possibilidades terapêuticas; Acolhimento; Preparação para cirurgia; Humanização do parto; Comemoração de aniversários dos servidores; Apoio Religioso e Espiritual; Riso no Hospital; Acompanhamento de Pacientes com Necessidades Especiais; Apresentação Musical; Cuidando do Cuidador; Reestruturação e Adequação da Área Física; Risco à Integridade Física e Mental do Trabalhador. Constitui-se uma comissão de trabalho, eleito um coordenador, para discutir os encaminhamentos". Surgindo o debate. Quais as finalidades do grupo? Grupos já existentes? Quem teve a primeira idéia? Autoria do projeto? a definição das prioridades e linhas de ações definiu e respondeu aos questionamentos em torno da Humanização no hospital público. a Humanização é uma das prioridades na área da Saúde, devendo nortear qualquer atividade que envolva usuários e profissionais da Saúde. a possibilidade de promover atendimentos humanizados ao valorizar o trabalho dos profissionais terá apoio com a Educação Permanente, garantindo o protagonismo dos mesmos dentro dos princípios da PNH. Contudo, sabemos que são complexas as realidades dos serviços de saúde em relação a esse tema, mesmo em condições adversas, as sementes desses ideais (transformadas em políticas) nascem, crescem e frutificam. a experiência na prática demonstra que humanização e humanidade, abordada na teoria, na verdade continua entre as ações das pessoas.

Gonçalves, Edson Luis; Castro, Maria Eduarda Oliveira. Caminhos e Momentos da Criação da Câmara de Política de Humanização da Assistência Hospitalar: a Humanização e a Humanidade nas Práticas, Rotinas e Ações Desenvolvidas em um Hospital Público. In: Anais do Congresso Internacional de Humanidades \& Humanização em Saúde [= Blucher Medical Proceedings, num.2, vol.1]. São Paulo: Editora Blucher, 2014. ISSN 2357-7282 DOI 10.5151/medpro-cihhs-10808 